\title{
Forensic prosecutor's speech as a speech genre
}

\author{
Irina A. Zyubina - Galina G. Matveeva - Marina R. Zheltukhina - Gennady \\ G. Slyshkin - Alevtina V. Shevchenko
}

\section{DOI: $10.18355 /$ XL.2017.10.03.25}

\begin{abstract}
In the article forensic prosecutor's speech as a speech genre is considered. The purpose of this article is to reveal the features of the stereotyped speech behavior of public prosecutors in the speech genre of the speech for the prosecution. The main difference between one genre from another one is not in its linguistic features, although each of the genres is characterized by the predominance, or, conversely, the absence of certain linguistic elements, but in the content orientation of a text and its functional purpose. Moreover, the purpose is to identify these peculiarities, first, it is important to determine the status of this speech genre. The composition of the prosecutor's speech in court is described. It is established that the speech for the prosecution consists of the following parts: 1) opening statement; 2) exposition of the factual circumstances of the act, the plot of the case; 3) analysis and evaluation of collected evidence of the case; 4) argumentation of determination the nature of the crime; 5) characteristics of the defendant and the victim; 6) proposals for the sentence or the verdict; 7) issues of compensation for the offense caused; 8) analysis of the causes and conditions that contributed to the offense, proposals to eliminate them; 9) conclusion. The speech for the prosecution contains the features of publicistic, official, scientific and colloquial styles, influences on the addressee.

Key words: forensic speech, prosecutor, speech genre, speech for the prosecution, lingua-pragmatics
\end{abstract}

\section{Introduction}

In modern linguistics, there is no generally accepted concept of a speech genre. There are many definitions of the term 'genre'. In our study, we go after M. M. Bakhtin, who defines speech genres as relatively stable types of utterances, which are produced by the areas of language use. Three things - thematic content, style and compositional structure - are inextricably linked in a statement and are identified by the specifics of each sphere of communication (Bakhtin, 1986: 428). From the point of view of lingua-pragmatics, a speech genre is a text produced in a typical situation of communication, which is reproduced in the communicative activity of native speakers. One characterizes a speech genre or another set of elements of the situation, as well as by a set of speech tasks solved in this situation. The main difference between one genre from another one is not in its linguistic features, although each of the genres is characterized by the predominance, or, conversely, the absence of certain linguistic elements, but in the content orientation of a text and its functional purpose.

\section{Theoretical research base: condition of problem's study}

The concept of M. M. Bakhtin distinguishes primary (simple) and secondary (complex) speech genres. Secondary speech genres - novels, plays, researches, great journalistic genres, etc. - appear in a more complex and a relatively highly developed organized cultural communication (primarily written) - fiction, scientific, sociopolitical, etc. In the course of their formation, they absorb and use various primary genres (for example, a phrase of an everyday dialogue) appeared in conditions of a 
spontaneous speech communication (Bakhtin, 1986: 430; Zheltukhina 2003; Zheltukhina 2014; 2015; Zheltukhina, Krasavsky, Slyshkin \& Ponomarenko 2016; Zheltukhina, Krasavsky, Ponomarenko, Aleshchanova \& Pavlov 2016; Zheltukhina, Slyshkin, Ponomarenko, Busygina \& Omelchenko 2016; Zheltukhina, Vikulova, Serebrennikova, Gerasimova \& Borbotko 2016; Zheltukhina, Zinkovskaya, Katermina \& Shershneva 2016; Zheltukhina, Mouzykant, Barabash, Ponomarenko, Morozova \& Mori 2017; Zheltukhina, Vikulova, Mikhaylova, Borbotko \& Masalimova 2017 etc.).

The speech for the prosecution in the court is a secondary speech genre, it can be referred to that type of oral public speech which most sharply differs from everyday speech and which is characterized by the following set of features:

1) there is one speaker and a lot of listeners;

2) the change of roles 'speaker' and 'listener' is not possible;

3) the relationships between the speaker and listeners are official, and they are characterized by inequality of the roles in the act of communication;

4) the theme is fixed (Golanova, 1993: 137).

Originally a text of the speech for the prosecution was born and existed as an oral speech, and only then it came to us in the form of a printed text. Because of this fact such paralinguistic intensifiers, as a timbre of the voice, a character and strength of the pronunciation (whisper, shout), facial expressions, gestures, movements of a body and extralinguistic sensitizers disappear, as well as psychic ground of speech perception, environment, social roles of the participants of the speech act, authoritativeness, the speaker's appearance, which are clearly present in oral speech and amplify the positive effect of the speaker's influence. A speech of a public prosecutor is represented as a text. Moreover, in an analysis of any text, which is a part of a joint practice of people, of processes of interpersonal interaction, it is taken into account the pragmatic intention of the text, that is its function (Najer, 1990: 5).

\section{Methodological bases and research methods}

Methodological basis of the research is the system approach that includes system and complex, systemic-structural and systemic-functional approaches. The purpose and problems of our work have defined the choice of analysis methods. In our work, such research procedures as hypothetical-deductive method, inductive method, descriptive and comparative method, definition analysis, elements of cognitive interpretation are used. Besides, in our research content analysis methods were applied to identification of the substantial party of speeches. The discourse analysis, studying structure and discourse units (speech acts), and the integrated approach to the analysis of mass media texts consisting in studying of their semantics, pragmatics, syntactics with use of the component, contextual and stylistic analysis were realized.

A forensic speech performs a number of interconnected functions: cognition, communication, psychological impact. A functional style stands in relation to a speech genre as its peculiar systemic manifestation. A functional style in a speech genre is manifested in a form of a purposeful selection of certain linguistic devices and techniques. A speech genre in relation to a style serves as its definite application in various situations of communication in a definite sphere of activity. A genre is not considered to be an equivalent to the concept of 'style', but a separate concept and at the same time parallel, relative to the concept of 'style'.

At the present stage of the scientific development, one of the major problems of stylistics is the classification of functional styles. In spite of a large number of recently appeared papers devoted to functional styles, there is still no consensus even on the number of existing styles. Both the number and characteristics of functional styles are different in the classifications of different researchers. It is 
advisable to select styles, not so much on theoretic, but on pragmatic grounds. In addition, it is because of pragmatic grounds we distinguish five styles. Therefore, they are an official style, a publicistic style, a scientific style, a colloquial style and a belles-lettres or fiction style (Zyubina, 2005: 32). A forensic speech as a genre of oratory has its own stylistic originality.

\section{Results and discussion}

The stylistic originality of the forensic speech is concluded in the following: firstly, a forensic speech at the same time refers to two styles of the literary language: publicistic and official, and secondly, it reflects the features of other styles of the literary language: scientific and colloquial. Thus, a speech genre of the speech for the prosecution is a complex functional-style formation, which uses the signs of different functional styles. Let us study in more detail the ways of the manifestation of the listed styles' (publicistic, official, scientific and colloquial) features in the speech genre of the speech for the prosecution.

First of all, we will analyze a speech of a public prosecutor from the point of view of the publicistic functional style and study the manifestation of the main feature of this style - the use of the open evaluation for the best effect - in a speech genre of the speech for the prosecution. The main goal of the publicistic style is to influence a listener or a reader for agitation and propaganda some of the ideas. Thus, for example, a public prosecutor of the former Soviet Union had a task not only to create an atmosphere of condemnation around a crime and a defendant, but a prosecutor should have been also an advocate of the communist ethics and morality. Before each public prosecutor in any socio-political system, there is a goal to create an atmosphere of conviction around a criminal. That is why each episode of a crime is reviewed and evaluated from this perspective. A speech of a public prosecutor has a bright negative character, both from the point of view of a negative component (the average speechgenre index of negative evaluation is $45 \%$, whereas the positive one is only $12 \%$ ) and from the point of view of the diversity of expression.

Designations of negative are more differentiated than the ones of positive also in the speeches of other kinds. This position is based on the studies of cognitive psychology, according to which the information associated with something unpleasant for a person, with negative emotions is more differentiated than the information with positive connotations. According to psychologists, a person distinguishes in more detail what is causing his discomfort and differentiates unpleasant emotions better than pleasant ones (Volf, 1986: 102).

An explicit expression of the negative attitude of an author may be made on the basis of invectives. An invective concludes in its semantics, expressive color, and an evaluation content component an intention of a speaker or a writer to humiliate, insult, dishonor, disgrace an addressee or the third person, and, what is more, in a sharp and cynical form - as much as it is possible. In modern Britain and Russia there is no invective vocabulary in the statements of prosecutors speaking in court. But such vocabulary is very characteristic for the public prosecutors of the USSR working in 20 s - 40s years of the XX century and to a lesser extent for the speeches for the prosecution working at the end of the XIX century in Russia (Zyubina, 2016: 27).

Invective vocabulary of the speeches for the prosecution is so diverse that one can divide it into the following types according to the principle of direct / indirect nomination (category):

\section{Direct nomination:}

1) Invective vocabulary originally denoting a person engaged in anti-social,

XLinguae Journal, Volume 9 Issue 3, June 2017, ISSN 1337-8384 
socially condemned activities (here and further, the translations of the examples are in the brackets following the examples):

1. Хохлов - преступник (Khokhlov is a criminal) (Pokrovskiy, 153).

2. Инглинк говорил, что таких рвачей надо терпеть (Inglink said one should bear such grabbers) (Kondrushkin, 467 - 468).

3. Троикисты и правые - это капитулянты (Trotskyists and rightwingers are trucklers) (Vyshinskiy, 325).

4. Кровью пионера обагрены руки правых изменников. (The hands of the right-wing traitors became stained with blood of the pioneer) (Pokrovskiy, 15).

2) The words, which have a bright negative connotation that is the main component of the meaning but in a specific time frame:

5. Они хотели вернуть кулаков и помещиков, действуя единым фронтом с фашистами (They wanted to return the 'kulaks' (rich peasants) and landlords acting as a united front with the fascists) (Pokrovskiy, 11-12).

6. Ни один сколько-нибудь серьезный заговор против Советской власти в СССР не обошелся без прямого и самого активного участия в нем иностранных капиталистов (None of any serious plots against the Soviet regime in the Soviet Union was without the direct and very active participation of foreign capitalists) (Vyshinskiy, 250).

3) Invective words containing in their meanings a negative evaluation, and, what is more, a very expressive evaluation of someone's personality:

7. Они вдохновляли силь кулачества и других подонков общества. (They inspired the forces of the kulaks and other dregs of the society) (Pokrovskiy, $13)$.

8. Русскому обществу нужно знать разоблаченную на суде правду об этой заразе (The Russian society should know the unmasking court truth about this plague) (Muraviov, 25).

\section{Indirect nomination:}

1) Metaphors referring to the names of animals, birds, insects, which cause unpleasant listeners' associations:

9. Партия эсеров превратилась в змею, жалящую в пяту (The Socialist Revolutionary Party has turned into a snake, stinging the heel) (Pokrovskiy, 200201).

10. Седков оставил такой сладкий кусок, что в нем увязли все слетевшиеся им попользоваться (Sedkov had left such a sweet piece, that all the flying together ones stuck in it) (Koni, 407-408).

Here (in the $10^{\text {th }}$ example) we can see a hint at a fly as a kind of insects.

11. В декабре Рыков каркает о непрочности Советской власти (In December Rykov croaks about the fragility of the Soviet power) (Vyshinskiy, 484).

In this example we cannot but feel the attempt of the public prosecutor to show Rykov as a bird or a crow to us.

12. Эта мышь, пойманная в мышеловку ... (This mouse, caught with a trap ...) (Vyshinskiy, 843-844).

13. Бухарин - это проклятая помесь лисицы и свиньи (Bukharin is a damn cross between a fox and a pig) (Vyshinskiy, 478).

2) Occasional (specially created) formations having the aim to humiliate or insult an addressee:

14. После крушения учредилки (то есть «Учредительное собрание») эсеры могли заняться пропагандой своих идей в массах (After the collapse of the 'uchredilka' (that is 'Constituent Assembly') socialist revolutionaries could promote their ideas to the masses) (Pokrovskiy, 42).

15. Очените роль этого господинчика, болтающего о том, что обер- 
бандит_и англо-германский шпион Трочкий уже в 1932 году сбросил свой «левацкий мундир» (Evaluate the role of this gentleman, chatting that the 'oberbandit' (that is 'subaltern bandit') and the Anglo-German spy Trotsky had already thrown off his 'levatskiy mundir' (it is a new expression for a uniform of the left-wing party) in 1932 (Vyshinskiy, 70 - 72).

16. Бухарин - патентованный лицемер и иезуит (Bukharin is a patented hypocrite and Jesuit) (Vyshinskiy, 765).

3) Names of literary characters and their forms, which have a negative characterization:

17. Тот самый Вандервельде - это Чичиков с его мертвыми душами (The very Vandervelde is Chichikov with his dead souls) (Lunacharskiy, 423).

This literary character (Chichikov) is from the famous "Miortviye dushi" ("Dead Souls") written by N. V. Gogol.

18. Меня мало интересует хлестаковщина Окладского (I am not so much interested in 'khlestakovshchina' of Okladskiy) (Kon, 221).

'Khlestakovshchina' is a word, which was made of the name 'Ivan Alexandrovich Khlestakov' who is the main character of Nikolay V. Gogol's "The Inspector-General".

4) Proper names with the deliberate changing of the number (the singular number into the plural one), claiming to be a generalization and reinforcing the negative assessment of the defendant and his crime:

19. Бухарины и Рыковы, Ягоды и Булановы, Крестинские и Розенгольцы, Икрамовы, Шаранговичи, Ходжаевы под руководством Троцкого делают свое черное дело... (Bukharins and Rykovs, Yagodas and Bulanovs, Krestinskies and Rosengoltzes, Ikramovs, Sharangoviches, Khodjaevs under the leadership of Trotsky do their dirty work ...) (Vyshinskiy, 114).

20. Тогда вслед за Окладскими прошли Дегаевы (Then after Okladskies there were Degayevs) (Kon, 690).

21. А у эсеров полковники Галкины стояли во главе армии. Колчаки, чаплины взяли в железные руки партию эсеров (And the Socialist Revolutionary Party had Generals Galkins standing at the head of the army. Kolchaks, Chaplins took into their iron hands the Socialist Revolutionary Party) (Lunacharskiy, 509, 616).

The analysis of the expression of the negative evaluation with the help of invective vocabulary showed that this phenomenon is a characteristic of 'totalitarian linguistic consciousness'. But at the present stage of the development of the Russian and British societies in the era of democratic changes this way of impact on a listener is not acceptable.

Use of a large number of high and solemn words by the public prosecutor also serves for the formation of evaluation as a way of influencing:

22. ...человек, который сейчас не испытывает никаких угрызений совести и боится только справедливого возмездия... ( ... a man, who is not conscience-stricken now and is afraid of only just retribution ...) (Trukhanov, 716 718).

23. Пора сорвать маску $c$ этих непроменьх благодетелей человечества (It is time to tear the mask from these uninvited benefactors of the mankind) (Muraviov, 18).

24. Троикизм и правые превратились в оруженосцев буржуазной контрреволючии (Trotskyism and the right-wing party became the sword-bearers of the bourgeois counter-revolution) (Vyshinskiy, 352).

The publicistic style is also characterized by the use of the words on social, political and ethical themes:

25. тайное сообщество, правительство, злодеяние (secret society,

XLinguae Journal, Volume 9 Issue 3, June 2017, ISSN 1337-8384 
government, evil deed) (Muraviov, 7, 13, 3);

In the speech for the prosecution, one can meet emotionally colored words, typical for the publicistic functional style:

26. отголоски того мирка, скромненький офицер с капитальцем (echoes of that 'microcosm', a 'modestish' officer with a 'kapitalets' (that is a very small amount of money) (Koni, 24, 43);

27. В этом вихре поднимается много и мути (In this whirlwind a lot of turbidity rises) (Lunacharskiy, 133).

As one can see, there is an abundance of high and solemn words, lexemes on social, political, moral and ethical themes, emotionally colored words in the speeches for the prosecution before the professional trial in the period of Soviet repressions and before the jury in all the periods.

Each court indictment in every state system or regime is a public political statement. A state prosecutor always acts not on his behalf, as other members of the trial, but on behalf of the state and the law. The specific purpose of the speech for the prosecution is to convince the court and all the other addressees sitting in the courtroom in the defendant's guilt, to make them agree with the conclusions offered by the prosecutor, and thereby to facilitate the proper formation of internal judicial opinions and legal consciousness of citizens. By his speech a public prosecutor helps to create an atmosphere of moral condemnation around the criminal, mobilizes the public opinion for fighting with crimes. Pleadings in court stimulate a thought; make a person thinking, so it is an important means of influence. In addition, the formation of the listeners' certain worldview, social and political consciousness is one more feature of the publicistic style. Therefore, the speech genre of the speech for the prosecution can be considered to be referred to the publicistic functional style of the modern language.

The following functional style in the frames of which the speech genre of the speech for the prosecution should be described is the official style. Accuracy and standardization of expression are characterized for this style. Let us analyze how these features are manifested in a court speech of a public prosecutor.

Speeches of the participants in the judicial debate are carried out in the legal field, and serve to the official relationships between the justice and the defendant, determine the position of the supervisory bodies of the state in a particular case. Therefore, an important social function of a judiciary speech allows us to speak about its correlation with the official style, which is primarily characterized by the extreme accuracy not allowing another point of view. A judicial speaker, analyzing the facts of the case, has no right of making a mistake to avoid wrong determination of the court. Every phrase, every word here must fully have a point of view of a speaker. It is typical for the official style to use words in their literal sense, the system of speech means here is to a large extent codified, so to some extent it is associated with the standardization of the expression (Matveeva, 1997: 22). Socially fixed formulas expressing legal relations definitely convey relevant concepts and facts. Here are some examples: 'legal action', 'jurisdiction of a court', 'principal suspect', 'direct / material evidence', 'attendant circumstances' and so on. Such expressions are met in any speech of a public prosecutor. The meaning of a legal cliché is fixed in legal documents and does not allow ambiguities. The terms of communication in an official sphere determine the appearance of standards. As everything in all legal relations is regulated, and communication is carried out according to certain standards which make this interaction easier, so speech standards turn out to be necessary and even desirable and justified. That is why there is an abundance of stable combinations of terminology (without emotion and expressivity).

From the point of view of syntax, one can see that complex sentences with various types of causal relations, homogeneous parts of the sentence and participle constructions are used in the official language of the speech for the prosecution. 
Subordinate conjunctions ('as', 'because of', etc.), as well as parenthetical words are also commonly used ('first of all', 'therefore', etc.) (Matveeva, 1997: 22).

More often, the official style is used for naming the corpus delicti elements, legal procedure, and procedural documents and for drawing conclusions about factual circumstances of a case and about punishment. The official style is characterized by the 'dryness' of presentation and by the lack of expressive means. Moreover, more frequently exactness and laconism are observed in the speeches for the prosecution before professional judges at the present moment.

We have discussed how the official style finds its attraction in the speech genre of the speeches for the prosecution. Now let us turn to the scientific functional style.

With regard to the scientific functional style, all the researchers point out such features of scientific speech as clearness of expression the thoughts, strong following the norms and terms (Senkevich, 1976: 36). For example:

28. Прошу квалифицировать данное деяние по статье 213.3 УК РФ как хулиганство, т.е. грубое нарушение общественного порядка, выражающее явное неуважение $\kappa$ обществу, $c$ применением насилия $\kappa$ гражданам, совершенное с применением предметов, используемых в качестве оружия (I ask you to qualify this act according to the Article 213.3 of the Criminal Code of the Russian Federation as hooliganism, that is a gross violation of public order expressing a clear disrespect for the society with the use of violence to citizens, committed with the use of objects used as a weapon) (Glyuzitskiy, 23 - 27).

Scientific speech has inherent logical accuracy, objectivity and consistency (Razinkina, 1972: 28). These traits help it to be methodologically convincing. The consistency is seen in the composition of the prosecutor's speech in court. The speech for the prosecution consists of the following parts (Enikeev, 1996: 571 - 572):

1. Opening statement.

2. Exposition of the factual circumstances of the act, the plot of the case.

3. Analysis and evaluation of collected evidence of the case.

4. Argumentation of determination the nature of the crime.

5. Characteristics of the defendant and the victim.

6. Proposals for the sentence or the verdict.

7. Issues of compensation for the offense caused.

8. Analysis of the causes and conditions that contributed to the offense. Proposals to eliminate them.

9. Conclusion.

The features and language means of the scientific style are most often seen in such parts, as "Analysis and evaluation of collected evidence of the case" and "Argumentation of determination the nature of the crime". The main goal of the scientific style is proof, and the main features arising from the abstraction and accuracy of thought are generalization and emphasized logicality consistency of presentation, when the dynamics of thinking is developing from the statement of the criminal acts to disproof of the opposite point of view, that is to the proof. Judgments and conclusions follow one after the other in the strict logical sequence. Especially, if in the case there is an absence of direct evidence of the defendant's guilt and the prosecution is based on circumstantial evidence, then the trial speech is characterized by strong logic and appropriate means of argumentation.

For the scientific style it is usual a great number of references to the sources of procedural legislation, to the facts:

29. Факт хищения Щербининым из квартиры Алимпиевой Л.Н. полностью подтверждается следующими доказательствами: показаниями потерпевшего Струкова, оглашенными показаниями потерпевщей Алимпиевой, протоколом опознания Струковым Щербинина, протоколом

XLinguae Journal, Volume 9 Issue 3, June 2017, ISSN 1337-8384 
изъятия вещей у Щербинина, протоколом опознания вещей Струковым, протоколом осмотра места происшествия (The fact of the theft from $L . N$. Alimpieva's apartment by Sherbinin is fully supported by the following evidences: the testimony of the victim Strukov, the disclosure of evidence of the injured Alimpieva, the protocol of Shcherbinin's identification made by Strukov, the protocol of seizure of the objects from Shcherbinin, the protocol of identification of the things made by Strukov, the protocol of inspection of the place of the incident) (Makhno, 9-15).

In the speeches for the prosecution there is a large number of citations which are usual for the scientific style:

30. Обязанность соблюдать законодательство о государственной тайне вытекает из общеправовой обязанности органов государственной власти, местного самоуправления, долюжностных лиц, граждан и их объединений соблюдать Конституцию Российской Федерации и законы (статья 15, часть 2 Конституичи РФ) (The obligation to comply with the state secrecy laws is derived from the common law duty of public authorities, local selfgovernment, officials, citizens and their associations to observe the Constitution and the laws of the Russian Federation (Article 15, Part 2 of the Constitution of the Russian Federation) (Kondakov, 21);

31. Согласно заключению судебно-медицинского эксперта, «Козыревой были причинены: три ушибленные раны правой лобной области и правой теменной области головы; переломы костей свода и основания черепа; ушиб вещества головного мозга; одиннадцать проникающих колото-резаных ранений груди с повреждением левого легкого» (According to the medical examiner, "Kozyreva suffered of: three contused wounds of the right frontal region of the head and of the right parietal region of the head, fractures of the calvarium and the skull base; contusion of the brain substance; eleven penetrating stab wounds to the chest with the injury of the left lung") (Abramov, 212).

32. As the judgment emphasized "this passage gives too little weight to the dangers of convicting on uncorroborated evidence of identity" (Andrade, 62 - 63);

33. He said / "Give me all the money..." (Whylie, $34-35$ ).

A trial speech is a purposeful volitional act in which a prosecutor proves the existence of a crime. That is why the frequent use of links to sources for specific facts, to opinions of competent people, which is characteristic of the scientific style, is reflected in the speech genre of the speech for the prosecution.

Thus, in the speech genre of the speech for the prosecution we can also observe elements of the scientific style.

Some researchers also say about bright conversational traits of modern judicial speeches (Makarova, 1985: 9). But more likely one can speak only about the elements of the colloquial style in a speech of a public prosecutor, as the goal of the colloquial style is to exchange thoughts, impressions, and communication. This goal does not match the purpose of persuasion, which is characteristic for a public speech at the court. Normative judicial speech is to be devoid of vulgar and everyday words, unnecessary neologisms. A lawyer's speech must be ethically restrained, difficulties and misfortunes of people must not get worse because of vulgar public mockery. However, in the speech for the prosecution we can observe lexemes, which are characteristic of the colloquial style: emotionally colored words, words with a figurative sense, parenthetical words, repetition of the words. For example:

- emotionally colored words:

34. гнусные преступления, великий советский народ, злейшие враги (filthy crimes, the great Soviet people, the bitter enemies) (Pokrovskiy, 2, 6, 12);

- words with a figurative meaning:

35. Первую скрипку играли белоэмигранты... Факты оживают $и$ начинают говорить (The first violin was played by the White-Guard émigrés (ones who left Russia with the White Guard in early Soviet period) ... The facts are getting 
alive and are starting to speak) (Vyshinskiy, 257, 518 - 519);

- parenthetical words:

36. Конечно... (Sure ... ) (Melnikov, 215);

37. ...наверное... ( ... maybe ... ) (Salnikov, 62);

38. Apparently... (Whylie, 196);

39. Perhaps ... (Tepleman, 53);

- repetition of the words:

40. Скоро исполнится три года..., три года... (Soon it will be three years ..., three years... ) (Krylenko $2-3)$;

41. Религиозность русского крестьянина, русского рабочего, русского обывателя... с целью классовой, с целью ниспровержения ... (The religiosity of the Russian peasant, the Russian worker, the Russian man in the street ... with the aim of the class, with the aim of overthrowing the ... ) (Krassikov, 38).

\section{Conclusion}

Thus, some elements of the colloquial style penetrate into the genre of the speech for the prosecution. Having examined the functioning of the speech genre of the speech for the prosecution, we came to the conclusion that the speech for the prosecution contains the features of publicistic, official, scientific and colloquial styles.

But the peculiarities of these styles are distributed in the speeches of the public prosecutors unevenly: the signs of the publicistic style dominate in the speeches for the prosecution in laying before a trial by jury in the XIX and XXI centuries in Russia, in the speeches by English-speaking prosecutors in laying before a trial by jury at the beginning of the XXI century and in the speeches of Russianspeaking prosecutors in laying before a professional trial in 20 s -40 s years of the XX century; and the signs of the official style dominate in the speeches for the prosecution of Russian-speaking prosecutors in laying before a professional trial at the beginning of the XXI century.

\section{Bibliographic references}

ABRAMOV, N.V. 2002. Obvinitel'naya rech'. Podderzhanie gosudarstvennogo obvineniya v sude s uchastiem prisyazhnykh zasedatelej / Pod red. S.I. Gerasimova. M., pp. 327-337.

ANDRADE, Q.C. Speeches for the prosecution. http://www.hrothgar.co.uk/WebCases/pc/frames/00/37.htm

BAKHTIN, M.M. 1986. Problema rechevykh zhanrov. Literaturno-kriticheskie stat'i. Moskva: Khudozhestvennaya literatura, pp. 428-472.

ENIKEEV, M.I. 1996. Osnovy obshhej i yuridicheskoj psikhologii. Moskva. ISBN 588240-027-9

GLYUZITSKIJ, A.V. Obvinitel'nye rechi. Protokoly sudebnykh zasedanij Kirovskogo rajonnogo suda g. Rostova-na-Donu.

GOLANOVA, E.I. 1993. Ustnaya publichnaya rech'. ZHanr publichnoj lektsii. Russkij yazyk v ego funktsionirovanii. Kommunikativno-pragmaticheskij aspekt. Moskva, 1993, pp. 137-157. ISBN 5-02-011112-0.

KONDAKOV, A. Rech' prokurora Aleksandra Kondakova. http://www.bellona.no/ru/index.html.

KONDRUSHKIN, I.S. 1965. Delo po obvineniyu vzyatochnikov i raskhititelej na transporte. Sudebnye rechi sovetskikh obvinitelej. Sbornik / Sost.: Aleksandrov G.N., Finn EH.A. M., pp. 104-118.

KONI, A.F. 1965. Obvinitel'naya rech'. Sudebnye rechi sovetskikh obvinitelej. 
Sbornik / Sost.: Aleksandrov G.N., Finn EH.A. M., pp. 88-102.

KONI, A.F. 1967. Obvinitel'naya rech' po «Delu o podloge zaveshhaniya kapitana gvardii Sedkova». Koni A.F. Poln. sobr. sochinenij. T.3. M., pp. 307-334.

KRASIKOV, P.A., 1965. Obvinitel'naya rech'. Sudebnye rechi sovetskikh obvinitelej. Sbornik / Sost.: Aleksandrov G.N., Finn EH.A. M., pp.70-83.

KRYLENKO, N.V. 1964. Sudebnye rechi. Izbrannoe. M., pp. 61-80.

LUNACHARSKIJ, A.V. 1965. Delo pravykh ehserov. Sudebnye rechi sovetskikh obvinitelej. Sbornik / Sost.: Aleksandrov G.N., Finn EH.A. M., pp.8-28.

MAKAROVA, Z.V. 1985. Oratorskoe iskusstvo v sude. Leningrad. ISBN 5-28800331-9.

MAKHNO, N.V. Obvinitel'nye rechi. Protokoly sudebnykh zasedanij Kirovskogo rajonnogo suda g. Rostova-na-Donu.

MATVEEVA, G.G. 1997. Osnovy kul'tury ustnoj rechi. Rostov-na-Donu: Rost. gos. arkhitektur. in-t. ISBN 5-94735-020-3

MEL'NIKOV, A.V. 2002. Obvinitel'naya rech'. Podderzhanie gosudarstvennogo obvineniya v sude s uchastiem prisyazhnykh zasedatelej / Pod red. S.I. Gerasimova. M., pp.361-369.

MURAV'EV, N.V. Obvinitel'naya rech' po «Delu 1-go marta». httr://juristy.ru/vip/muravyov.htm.

NAER, V.L. 1990. Pragmatika teksta i ee sostavlyayushhie. Pragmaticheskij aspekt predlozheniya i teksta. Leningrad: LGPI.

POKROVSKIJ, M.N. 1965. Delo pravykh ehserov. Sudebnye rechi sovetskikh obvinitelej. Sbornik / Sost.: Aleksandrov G.N., Finn EH.A. M., pp. 28-36.

RAZINKINA, N.M. 1972. Stilistika anglijskoj nauchnoj rechi. Moskva, 1972.

SAL'NIKOV, V.N. 2002. Obvinitel'naya rech'. Podderzhanie gosudarstvennogo obvineniya v sude s uchastiem prisyazhnykh zasedatelej / Pod red. S.I. Gerasimova. M., pp. 337-346.

SENKEVICH, M.P. Stilistika nauchnoj rechi i literaturnoe redaktirovanie nauchnykh proizvedenij. Moskva, 1976.

SHEVCHENKO, A.V. 2003. Information Security Issues in Judicial Activity. Round table's verbatim report. June, 2, 2003 / Ed. Y.V. Tsybakin, E.K. Volchinskaya. Moscow. The Publishing House of the State Duma, 37, [1].

SLYSHKIN, G.G. 2007. Kontsept lichnosti kak ehlement lingvokul'turnoj istoriosfery (na materiale kontsepta «Talejran»). Ethnohermeneutik und kognitive Linguistik / Hrsg. von R.D. Kerimov. Landau: Verlag Empirische Pädagogik, pp. 81-88. ISBN 978-3-937333-59-5.

TEMPLEMAN. Speeches for the prosecution. http://www.hrothgar.co.uk/WebCases/pc/frames/00/45.htm

TRUKHANOV, G.V. Obvinitel'nye rechi na sudebnykh zasedaniyakh Oblastnogo suda g. Rostova-na-Donu.

VOL'F, E.M. 1986. Otsenochnoe znachenie i sootnoshenie priznakov «khorosho / plokho» // Voprosy yazykoznaniya, 5, pp. 98-106. ISSN 0373-658X

VYSHINSKIJ, A.YA. 1955. Sudebnye rechi. Moskva.

WHYLIE, O. Speeches for the prosecution.

http://www.hrothgar.co.uk/WebCases/pc/frames/00/37.htm

ZHELTUHINA, M.R. 2003. Tropologicheskaya suggestivnost' massmedial'nogo diskursa: o specifike rechevogo vozdejstviya tropov v yazyke SMI. Moskva Volgograd: IYA RAN, VF MUPK. ISBN 5-88234-568-5.

ZHELTUKHINA, M.R. 2015. Institutional, Stereotypical and Mythological Media Markers of Modern Society. Biosciences Biotechnology Research Asia, April, 12 (1), pp. 913-920. ISSN 0973-1245, eISSN 2456-2602.

ZHELTUKHINA, M.R. - KRASAVSKY, N.A. - PONOMARENKO, E.B. ALESHCHANOVA, I.V. - PAVLOV, P.V. 2016. Political Facebook Posts Using 
Ideological Symbols for Media Image Designing of Russia as Enemy. International Journal of Environmental and Science Education, 11(18), pp. 12005-12013. eISSN 1306-3065.

ZHELTUKHINA, M.R. - KRASAVSKY, N.A. - SLYSHKIN, G.G. PONOMARENKO, E.B. 2016. Utilitarian and Aesthetic Values in the Modern German Society (Through the Example of Print Media Advertisements). IEJMEMathematics Education, 11(5), pp. 1411-1418. ISSN 2468-4945.

ZHELTUKHINA, M.R. - MOUZYKANT, V.L. - BARABASH, V.V. PONOMARENKO, E.B. - MOROZOVA, E.V. - MORI, S. 2017. Russian and Japanese Younger Generations in Search for a New Media Product. Man In India, 97 (3), pp. 223-236. ISSN: 0025-1569.

ZHELTUKHINA, M.R. - SLYSHKIN, G.G. - PONOMARENKO, E.B. BUSYGINA, M.V. - OMELCHENKO, A.V. 2016. Role of Media Rumors in the Modern Society. International Journal of Environmental and Science Education, 11(17), pp. 10581-10589. eISSN 1306-3065.

ZHELTUKHINA, M.R. - VIKULOVA, L.G. - MIKHAYLOVA, S.V. BORBOTKO, L.A. - MASALIMOVA, A.R. 2017. Communicative Theatre Space in the Linguistic and Pragmatic Paradigm. XLinguae Journal, Volume 10 Issue 2, April 2017, pp. 85-100. ISSN 1337-8384.

ZHELTUKHINA, M.R. - ZINKOVSKAYA, A.V. - KATERMINA, V.V. SHERSHNEVA, N.B. 2016. Dialogue as a Constituent Resource for Dramatic Discourse: Language, Person and Culture. International Journal of Environmental and Science Education, 11(15), pp. 7408-7420. eISSN 1306-3065.

ZYUBINA, I.A. 2005. Pragmalingvisticheskij aspekt rechevogo povedeniya russkogovoryashhego i anglogovoryashhego gosudarstvennogo obvinitelya. Diss. ... kand. filol. nauk. Rostov-na-Donu: JUFU.

ZYUBINA, I.A. 2016. Individual'noe i stereotipnoe rechevoe povedenie russkogovoryashhikh i anglogovoryashhikh gosudarstvennykh obvinitelej. Rostov-naDonu: JUFU.

Words: 5576

Characters: $37200(20,67$ standard pages $)$

Associate Prof. Irina Anatolevna Zyubina, PhD.

Institute of Philology, Journalism and Cross-Cultural Communication

Southern Federal University

Universitetsky Lane 93

344006 Rostov-on-Don

Russia

irinazyubina@gmail.com

Prof. Galina Grigoryevna Matveeva, DrSc.

World Languages and Cultures Department

Don State Technical University

Gagarin Square 1

344000 Rostov-on-Don

Russia

gegemat2337633@rambler.ru

Prof. Marina Rostislavovna Zheltukhina, DrSc.

Institute for Foreign Languages 
Volgograd State Socio-Pedagogical University

Lenin Prospect 27

400066 Volgograd

Russia

zzmr@mail.ru

Prof. Gennady Gennadievich Slyshkin, DrSc.

Institute of Law and National Security

Russian Presidential Academy of National Economy and Public Administration Vernadsky Prospect, 84/2, 6

119606 Moscow

Russia

ggsl@yandex.ru

Prof. Alevtina Vladimirovna Shevchenko, DrSc.

Institute of Law and National Security

Russian Presidential Academy of National Economy and Public Administration Vernadsky Prospect, 84/2, 6

119606 Moscow

Russia

titotin@yandex.ru 